\title{
Bacteriocins Produced by LAB Isolated from Cheeses within the Period 2009-2021: a Review
}

\author{
Lorena Trejo-González ${ }^{1}$ - Ana-Estefanía Gutiérrez-Carrillo ${ }^{1}$ · Adriana-Inés Rodríguez-Hernández ${ }^{1}$. \\ Ma. del Rocío López-Cuellar ${ }^{1} \cdot$ Norberto Chavarría-Hernández $^{1}$ (i)
}

Accepted: 20 July 2021 / Published online: 3 August 2021

(c) The Author(s), under exclusive licence to Springer Science+Business Media, LLC, part of Springer Nature 2021

\begin{abstract}
A survey is presented concerning original research articles published in well-reputed scientific journals on the isolation of lactic acid bacteria (LAB) from cheeses worldwide, where researchers evaluated the bacteriocin production by such isolates in searching for novel functional peptides that can exhibit potential for biotechnological applications. Seventy-one articles were published in the period of study, with contributions being American (45\%), Asiatic (28\%), and European (21\%), being Brazil-USA-Mexico, Turkey-China, and France-Italy the countries that contributed the most for each said continent, respectively. Most of the isolated LAB belong to the genera Enterococcus (35\%), Lactobacillus (30\%), Lactococcus (14\%), and Pediococcus (10\%), coming from soft (64\%), hard (27\%), and semi-hard (9\%) cheeses, predominantly. Also, scholars focused mainly on the food biopreservation (81\%) and pharmaceutical field (18\%) potential applications.
\end{abstract}

Keywords Antimicrobial peptides $\cdot$ Novel bacteriocins $\cdot$ Functional additives $\cdot$ Artisanal cheese $\cdot$ Fermentation $\cdot$ Purification

\section{Introduction}

Lactic acid bacteria (LAB) are a key heterogeneous group of microorganisms that have provided diverse benefits to the human being, since ancient times, in fact determining traditions, culture, and health of civilizations. LAB are Gram-positive, catalase-negative, non-spore-forming, and anaerobic, producing lactic acid as the primary end product of fermentation. Important members belong to the genera Lactobacillus, Paralactobacillus, Holzapfelia, Amylolactobacillus, Bombilactobacillus, Companilactobacillus, Lapidilactobacillus, Agrilactobacillus, Schleiferilactobacillus, Loigolactobacilus, Lacticaseibacillus, Latilactobacillus, Dellaglioa, Liquorilactobacillus, Ligilactobacillus, Lactiplantibacillus, Furfurilactobacillus, Paucilactobacillus, Limosilactobacillus, Fructilactobacillus, Acetilactobacillus, Apilactobacillus, Levilactobacillus, Secundilactobacillus, Lentilactobacillus, Pediococcus, Lactococcus,

Norberto Chavarría-Hernández norberto@uaeh.edu.mx

1 Cuerpo Académico de Biotecnología Agroalimentaria, Instituto de Ciencias Agropecuarias, Universidad Autónoma del Estado de Hidalgo. Av, Universidad Km 1, Rancho Universitario, C.P. 43600 Tulancingo, Hidalgo, Mexico
Streptococcus, Leuconostoc, Weissella, Enterococcus, and Oenococcus, among others $[1,86]$. LAB can produce diverse substances with antimicrobial activity, one type of them of proteinaceous nature, called bacteriocins, ribosomally synthesized by bacteria $[2,3]$. The classification of bacteriocins is a matter continuously updated, and excellent references are discussing this based on the physicochemical properties, molecular weight, the inclusion of particular amino acids in the structure, heat stability, containing other compounds like lipids or carbohydrates, cyclic molecules, involved genetics, among other characteristics $[4,5]$. There are three types of bacteriocins produced by Gram-positive bacteria: Class I or lantibiotics $(<5 \mathrm{kDa}$, heat-stable with characteristic amino acids, like lanthionine; i.e., nisin, mersacidin); Class II ( $<10 \mathrm{kDa}$, heat-stable, without lanthionine; i.e., pediocin, plantaricin); Class III ( $>30 \mathrm{kDa}$, thermolabile; i.e., helveticin) [6].

Essential sources of LAB are the traditional fermented foods, both animal and vegetable origin (i.e., (product/primary raw material): Kimchi/cabbage; Kefir/cow's milk; Pozol/maize; Amazake/rice; Cheddar cheese/milk; Plaasom/fish; Sausages/meat) [7, 8] among other possible sources as feces [9, 10]), skin [11], mouth [12], vagina [13], and herbs [14]. 
Even many groups worldwide are conducting research on bacteriocins; nowadays, there are just a few bacteriocins that are authorized for their use in different countries and found at the commercial level. Examples of these are (a) nisin, a lantibiotic bacteriocin produced by a cheese-making starter, $\mathrm{Lac}$ tococcus lactis subsp. lactis [15], considered a food additive with the GRAS status (i.e., generally recognized as safe) [16] and authorized in Europe as the food additive E234 [17], and (b) colicins, also recognized as GRAS additives [18] produced by Escherichia coli, to reduce the levels of E. coli on meat food products. Furthermore, the bacteriocin business is important with high growth expectations. Just concerning nisin, it is expected to encompass a market of 553 USD million by 2025 , just considering food applications (i.e., meat, poultry, and seafood; dairy; beverages; bakery and confectionery; canned and frozen products (https://www.marketsandmarkets.com)). Moreover, in recent times, researchers have envisaged having more comprehensive applications of bacteriocins, including the combat of antibiotic-resistant pathogenic bacteria [19], the control of certain types of cancer by inducing the apoptosis process [20,21], and even as a possible alternative as antiviral therapy against COVID-19 [22, 23], among other applications. Exciting times are waiting for us in this field.

Furthermore, cheeses have been valuable sources for the isolation of $\mathrm{LAB}$ with the purpose, among others, of discovering novel bacteriocins that can be useful to solve problems concerning food preservation and pharmaceutical/medical matters. Moreover, this is possible, at least partially, due to cheese technology being about 9000 years old, giving humans the possibility to interact with microbial populations which have evolved in a vast catalogue of LAB available today, considering the lots of cheese types that are present all over the world [24, 25]. That is the reason for conducting this review concerning original research articles on the isolation of LAB from cheeses, where researchers have focused on producing bacteriocin strains with potential biotechnological value during the period 2009-2021.

\section{Original Research Articles Database Construction}

A database of 71 articles published on LAB producing bacteriocins isolated from cheese was built from 2009 to 2021. The article database was based on a search in the Dialnet, Redalyc, Scielo, Science Direct, Scopus, Springer Link, and Wiley databases. The articles were thoroughly checked to avoid duplication. All references were organized in a Microsoft Excel ${ }^{\mathrm{TM}}$ spreadsheet. The data were initially classified according to the year of publication and the country of origin of the corresponding author. The isolation of LAB from cheese for the production of bacteriocins showed that the most productive years were 2017, 2019, and 2020 (Fig. 1A), where 27 original research articles were published, and the years 2012 and 2015 showed important contributions with a total of seven publications per year.
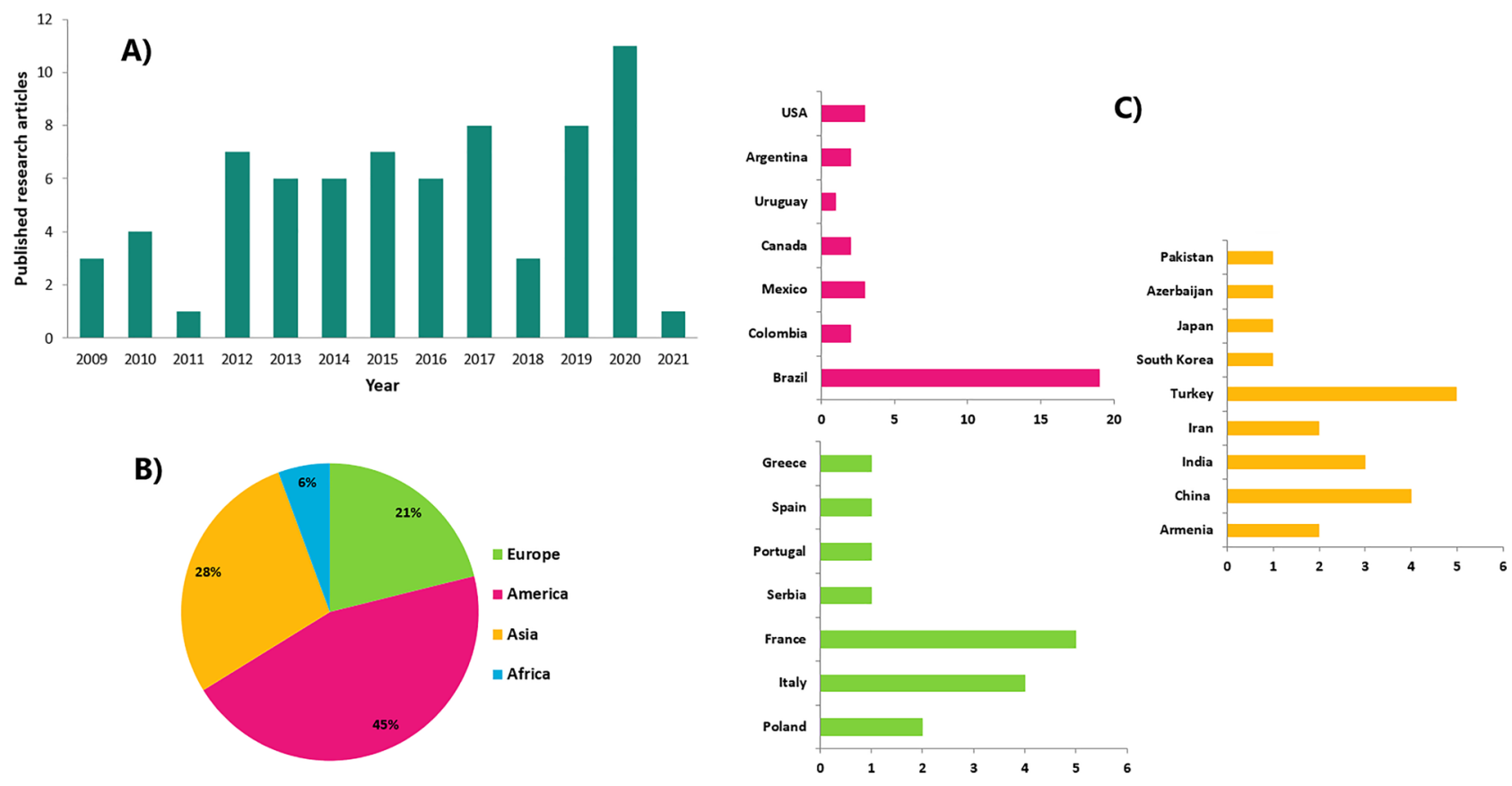

Fig. 1 Original research articles on bacteriocin-producing lactic acid bacteria isolated from cheeses from the period 2009-2021, according to Dialnet, Redalyc, Scielo, Science Direct, Scopus, Springer Link,

and Wiley databases. A Published articles by year. B Contributions percentage by continent. C Contributions by country, in America (pink), Asia (yellow), and Europe (green) 


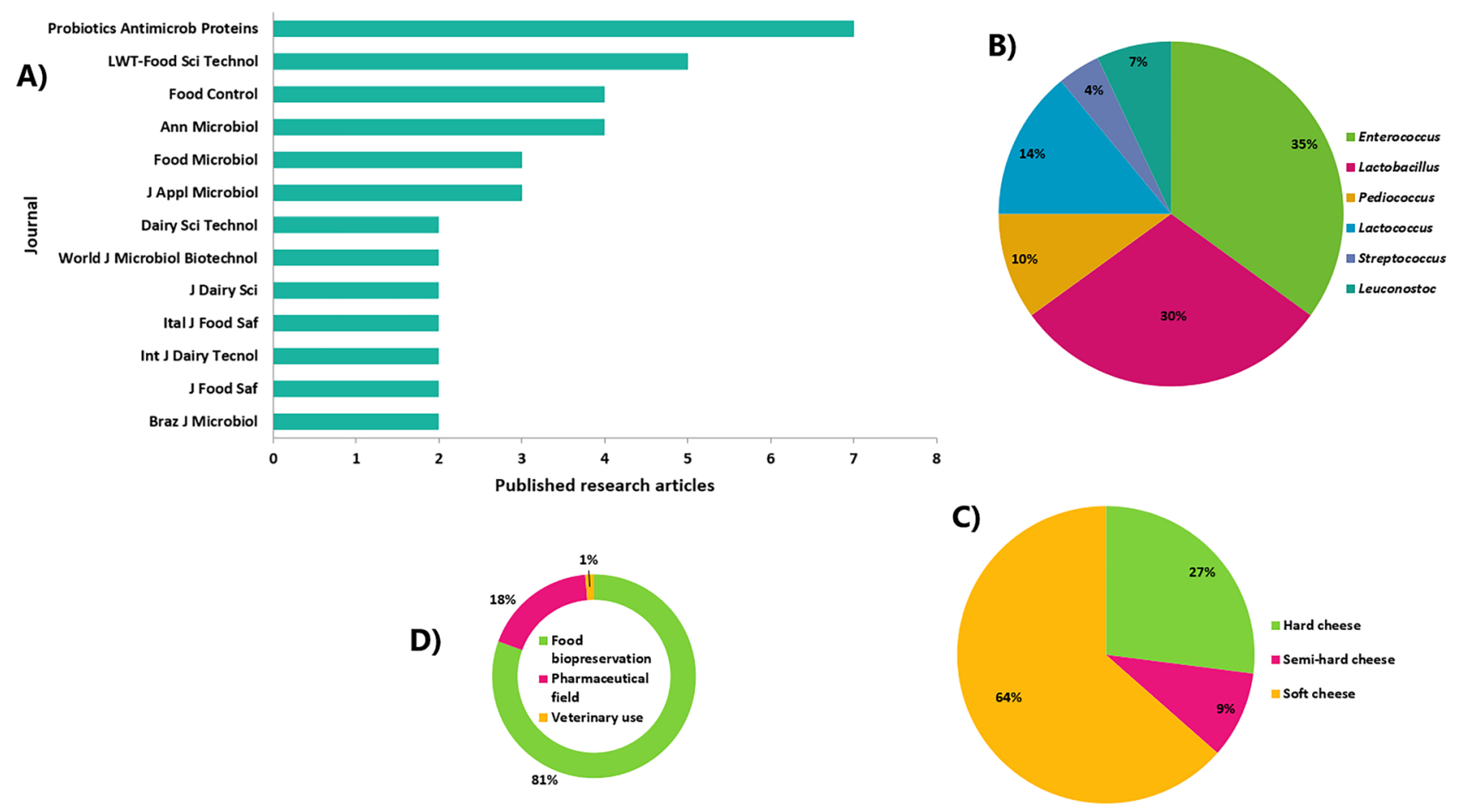

Fig. 2 Original research articles concerning bacteriocinogenic lactic acid bacteria (LAB) isolated from cheeses from the period 20092021. A Main reputed journals where articles were published. B

The data showed that $66 \%$ of the collected articles were made in a single nation and $34 \%$ were part of multinational research. Concerning the articles made in collaboration by several nations, $67 \%$ involved labs from two nations, $25 \%$ corresponded to articles made with the collaboration of three nations, and $8 \%$ belong to articles developed through the contribution of more than three nations. Worldwide, America, Asia, Europe, and Africa contributed with 45, 28, 21, and $6 \%$, respectively, to the information reported on original investigations related to $\mathrm{LAB}$ isolated from cheese in order to produce bacteriocins in the last decade (Fig. 1B), being
Main genera of LAB reported by scholars. C Percentage of types of cheeses where LAB are isolated. D Main potential fields of application

Brazil, Turkey, and France the countries that contributed the most to the research in this field (Fig. 1C).

According to the data collection, thirteen reputed journals published the majority of the research articles, being Probiotics and Antimicrobial Proteins the one that contributed the most with seven articles, followed by LWT-Food Science and Technology with five articles, and Annals of Microbiology and Food Control with four articles each one (Fig. 2A). Table 1 presents the top ten most cited articles according to the Web of Science ${ }^{\mathrm{TM}}$ Core Collection (WOS, https://publons.com/about/home/), being the Canadian work
Table 1 Most cited original research articles published in the period 2009-2021, concerning the bacteriocinproducing lactic acid bacteria isolated from cheeses, on the basis of the Web of Science ${ }^{\mathrm{TM}}$ Core Collection

\begin{tabular}{lllll}
\hline Rank & Article & Total citations & Corresponding author & Country \\
\hline 1 & Yang et al. [26] & 102 & Fan, L & Canada \\
2 & Sawa et al. [70] & 84 & Sonomoto, K & Japan \\
3 & Favaro et al. [71] & 65 & Favaro, L & Italy \\
4 & Alegria et al. [72] & 61 & Mayo, B & Spain \\
5 & Vera Pingitore et al. [39] & 60 & Vera Pingitore, E & Argentina \\
6 & Simova et al. [73] & 50 & Beshkova, D. B & Bulgaria \\
7 & Rushdy and Gomaa [74] & 38 & Rushdy, A. A & Egypt \\
8 & Chacon Ruiz Martinez et al. [47] & 36 & Chacon Ruiz Martinez, R & Brazil \\
9 & Moraes et al. [75] & 31 & Nero, L. A & Brazil \\
10 & Ahmadova et al. [54] & 27 & Haertlé, T & France \\
\hline
\end{tabular}


of Yang et al. [26] the most cited article in the decade of study, with 102 citations in total.

In this study, a metadatabase of 68 original research articles published in Bibtex format was processed with the Bibliometrix software package and R-studio for the scientific mapping analysis [27]. Figure 3 shows the conceptual structure of a framework using a keyword co-occurrence network that denotes the more common concepts that were highlighted as general research topics for the production, purification, and characterization of bacteriocins produced by LAB isolated from cheese in the period 2009-2021. The map in Fig. 3 shows the most used keywords in this field, involving four thematic clusters: food (red), cheese (blue), characterization and production (green), and genetic focus (purple). The first group includes most of the articles and references to the isolated LAB, the identification of strains, and the purification of produced bioactive peptides as well as the description of the antimicrobial activity against indicator microorganisms such as Listeria monocytogenes and Staphylococcus aureus, among other factors related to these keywords within the analyzed articles. The second group refers to the isolation sources of $\mathrm{LAB}$, which in this review has focused on cheese. It also mentions some isolated bacteria, the most representative and the most common bacteriocins within the collected articles. The third set is related to the biosynthesis of bacteriocins, as well as important responses such as antimicrobial activity against antibiotic-resistant pathogens (like pathogenic microorganisms isolated in nosocomial [28, 29]), the mechanism of action, and the conditions under which these bacterial metabolites can be produced. The fourth group includes studies on the genetics of the isolated LAB and the fermentation conditions for producing the studied bacteriocins.

Conceptual Structure Map - method: MCA

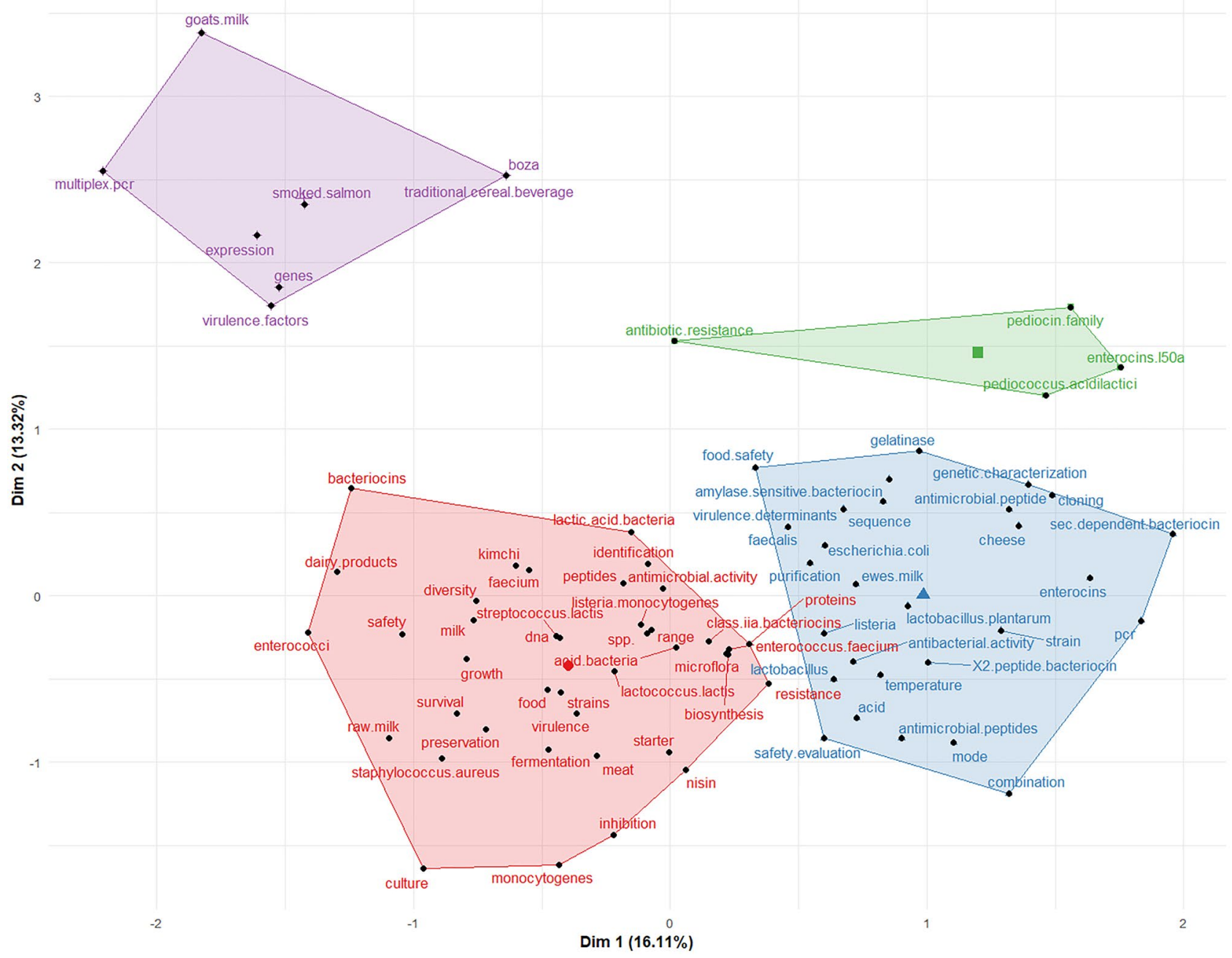

Fig. 3 Conceptual map and clusters of keywords in 68 original research articles from Web of Science ${ }^{\mathrm{TM}}$ Core Collection, concerning bacteriocinproducing lactic acid bacteria isolated from cheeses from the period 2009-2021 


\section{Cheeses as Sources of Bacteriocin-Producing LAB}

LAB are a phylogenetically diverse group of Grampositive bacteria characterized by some common traits, whether morphological, metabolic, or physiological [30]. The production of lactic acid characterizes them as the final metabolic product of carbohydrate fermentation. They are shaped like cocci or bacilli; most are aerotolerant anaerobes, catalase, and oxidase negative and synthesize ATP in the lactic fermentation of carbohydrates; they lack cytochromes and do not form spores [31].

Most LAB can only get energy from sugars and other related compounds. Due to their limited biosynthetic capacity, they are very nutritionally demanding and require complex growth factors such as amino acids, vitamins, purines, and pyrimidines; therefore, they are frequently located in habitats rich in nutrients, characterized by the presence of soluble carbohydrates and degradation products from proteins and vitamins, and with low oxygen tensions such as milk and dairy products, like cheese, among other ecological environments [32, 33]. Within dairy products, cheese is understood as the soft, semi-hard, hard, and extra-hard product, matured or unripened, and that can be coated, in which the proportion between whey proteins and the casein is not higher than that of milk, obtained by total or partial coagulation of milk protein, skim/skim milk, partially skim/skim milk, cream, whey cream or buttermilk or any combination of these materials, by the action of rennet or other suitable coagulants, and by partial draining of the whey that emerges as a result of said coagulation, respecting the principle that the production of cheese results in a concentration of milk protein (especially the casein portion) and that, consequently, the protein content of the cheese should be higher than that of the mixture of dairy materials already mentioned [30, 34-36]. The different types of cheese depend on the used milk (i.e., mammal species, fat content), the particular species of bacteria and/or fungi involved in the process, and the aging time and other processing treatments [37]. LAB play different roles in the cheese-making process. Some species are more involved in fermentation, and others are primarily involved in maturation. They carry out the initial acidification of the milk, promoting coagulation, curd strength, gel syneresis, and dissolution of colloidal calcium phosphate, among others [25]. LAB can be deliberately added as starter cultures or occurred as natural native microbiota of the raw milk selected by the conditions of the fermentation process, allowing microbial diversity, and contributing to the significant differences in organoleptic characteristics found in raw milk cheeses [38]. Furthermore, the presence of LAB in fermented foods improves the safety, innocuousness, and shelf life of foods through the production of various antimicrobial compounds, organic acids (lactic, acetic, etc.), hydrogen peroxide, diacetyl, and antimicrobial peptides (i.e., bacteriocins) [26, 39].

In this survey, based on the collected articles, the main LAB strains that have been isolated from cheese belong to the following genera: Enterococcus, Lactobacillus, Lactococcus, Pediococcus, Leuconostoc, and Streptococcus, where the first three genera contributing 35,30 , and $14 \%$, respectively, of the isolated $\mathrm{LAB}$ during the analyzed period (Fig. 2B). Furthermore, $64 \%$ of the reported bacteriocinogenic-LAB isolations came from soft cheeses (moisture $>55 \%$ ), 27\% from hard-cheeses (moisture $20-42 \%$ ), and $9 \%$ from semi-hard cheeses (moisture 45-55\%) [24] (Fig. 2C), being the food application focus (i.e., preservation additives; probiotic function) the main interest $(81 \%)$, followed by the pharmaceutical applications (18\%; i.e., bacteriocins as alternatives to "common" antibiotics; the antitumoral function), and the still scarce but not less critical, veterinary uses (i.e., animal health) (Fig. 2D). Moreover, most of the authors use "standard" techniques for the isolation of LAB and its characterization: Media MRS and M17 for bacterial growth; commercial kits like API 50 CHL and API 20 Strept, and catalase test for biochemical profile; Gram staining and 16S rDNA gene sequencing for taxonomy, mainly.

In South America, relevant work has been conducted in Brazil (Fig. 1C). Pediococcus pentosaceus was isolated from ripened Minas cheese, an artisanal cheese made with raw cow's milk, detecting the presence of the pediocin PA-1 gene in the LAB isolated [40]. Cabral Carvalhaes Costa et al. [41] isolated L. lactis QMF11 from fresh Minas cheese. Two strains of Lactobacillus plantarum, LCN 17 and LCN 43, were isolated from artisanal ewe's cheese from Rio Grande do Sul [42]. Two strains of Enterococcus faecium, EM485 and EM925, possessing genes encoding for enterocin A and B, were isolated from artisanal Coalho cheese [43]. Ent. faecium 130 was recovered from mozzarella cheese by Tulini et al. [44]. The bacteriocinogenic LAB, Lact. plantaturum B391, was isolated from Tomme-de-Savoie cheese of French origin made with raw skimmed cow's milk, ripened for 2-4 months [45]. The bacteriocinogenic Lact. pentosus B231 was isolated from the Portuguese Pico cheese, an artisanal cured food with a protected designation of origin (PDO) produced in the Azores Islands [46]. Bacteriocinogenic Lact. plantarum ST71KS was isolated from Bulgarian goat milk feta cheese, which produces a class IIa bacteriocin [47].

Mexican cheese is also studied as LAB sources. Ped. acidilactici QC38 which produces the bacteriocin Pediocin PA-1 was isolated from Cotija cheese, a ripened artisanal product of raw milk, produced in the state of Michoacán 
[48]. Ent. durans 41D which produces Duracin GL was isolated from Mexican-style cheese samples [49].

In the case of Europe, there were also valuable contributions in the analyzed period (Fig. 1C). Eight bacteriocinproducing strains identified as Lact. lactis and Ent. faecalis were isolated from artisanal Portuguese Pico cheese produced in the Azores [50]. Two Lact. plantarum strains, Os4 and Kor 14, isolated from Polish regional cheeses (Oscypek and Korycinski) exhibit important activity against Staph. aureus and potential as probiotics [51]. Lact. plantarum LpU4, which produces a novel plantaricin, was isolated from Italian "Pecorino" cheese, an artisanal raw sheep's milk food [52]. Lactococcin G-producer L. lactis subsp. lactis BGBM50 strain was isolated from artisanal semihard cheese produced in the village of Žanjic, Montenegro [53]. Ent. faecium AQ71, an enterocin producer strain, was isolated from artisanal Motal cheese produced by nomadic tribes of Azerbaijan [54].

On the other hand, in Asia, Turkey has made important contributions (Fig. 1C). Five strains of Lact. plantarum isolated from Lighvan cheese, an artisanal raw sheep's milk food of Iran, produced compounds of proteinaceous nature that exhibited antifungal activity [55]. From Kouzeh cheese, a traditional cheese in north-western Iran, Lact. plantarum strains were isolated, showing vigorous antimicrobial activity against Staph. aureus and Staph. epidermidis [56]. Lact. rhamnosus BTK 20-12, a potential probiotic which produces two bacteriocins (BCN1 and $\mathrm{BCN} 2$ ), was isolated from the artisanal salty cheese of Armenia [29]. Twelve strains belonging to five species of enterococci (i.e., Ent. faecium, Ent. faecalis, Ent. durans, Ent. gallinarum, and Ent. italicus) were isolated from traditional white semi-hard cheese of the Northern Black Sea region of Turkey. The presence of enterocin B gene was evidenced in all tested enterococci [57]. Ent. faecium $\mathrm{T} 1$, isolated from Chinese Tibet cheese, produced enterocin T1, which inhibit the growth of some Grampositive and negative bacteria of economic importance (i.e., Pseudomonas putida, Ps. aeruginosa, Ps. fluorescens, E. coli, Salmonella typhimurium, Shigella flexneri, Sh. sonnei, Staph. aureus, and L. monocytogenes) [58]. Lact. plantarum SLG1 was isolated from traditional Qinghai yak cheese from Tibet and has the ability to produce a novel plantaricin that exhibited antimicrobial activity against diverse Gram-positive and negative bacteria, and yeasts, all of economic importance [59].

Further, in Africa, L. lactis subsp. lactis A15 and Ent. faecium A15 were isolated from traditional Egyptian cheeses (i.e., Domiatti, Ras, and Kareish cheeses), and genetic analysis exhibited the presence of nisin $\mathrm{Z}$ and enterocin $B$ genes, respectively, suggesting the potential of these strains in biopreservation applications [60].
Production, Purification, and Characterization of Bacteriocins

The search for new LAB with the capacity of producing novel bacteriocins with application potential in diverse fields (i.e., food, pharmacy, and veterinary) has considered cheeses as good sources for such bacteria. Most of the time, once the isolated LAB is re-activated, the bacteriocin production is carried out in batch systems and occurred during the exponential growth phase or at the end of it, being frequently directly correlated to the produced bacterial biomass, which usually occurred during the first $24 \mathrm{~h}$ of fermentation (Table 2). Also, researchers commonly use complex media for these purposes, being the MRS medium [61] the most frequently used, but M17 [62] and tryptoneyeast extract-lactose (TYL) [63] media are also used for bacteriocinogenic LAB cultivation. These media are rich in carbohydrates, proteins, and peptides that can act as inducers for the bacteriocin synthesis, which is also affected by the fermentation conditions (i.e., temperature, $\mathrm{pH}$, agitation, aeration) [64]. LAB produce bacteriocins by ribosomal synthesis, giving inactive molecules which become biologically active after chemical modifications [65]. Also, bacteriocins can be produced constitutively or by conditional systems (i.e., Quorum sensing) [66], which involves complex regulation systems (i.e., ComD/E, ComR/S) mediated by genes located in the LAB-chromosome in association with transposons and plasmids (i.e., genes encoding enterocins: entA, entB, entP, entQ, L50A). Moreover, it is common for $\mathrm{LAB}$ to produce more than one bacteriocin (Table 2) [67].

Once the fermentation is finished, the recovery of the produced bacteriocins is carried out based on their physico-chemical properties. This task is a challenge due to the presence of a mixture of bacteriocins with diverse chemicals (i.e., other metabolic products, residual nutrients) in the culture broth, which usually requires a carefully tuned method specific for the produced bacteriocins [68]. Researchers based the downstream processing by the precipitation of peptides with ammonium sulfate from the culture broth supernatants, after centrifugation to separate LAB cells, then involving steps like dialysis and diverse chromatographic separations (i.e., cation exchange, gel filtration, hydrophobic interaction, and reverse-phase liquid chromatography) where the used $\mathrm{pH}$ is an essential factor (Table 2). Pei et al. [59] explored an innovative methodology for bacteriocin separation, involving the adsorption of the produced bacteriocins into magnetic nanoparticles, later isolating them with a magnetic column.

In order to envisage possible applications of the bacteriocins produced by the LAB isolated from cheeses (i.e., food preservation, systemic infections, woman care, 


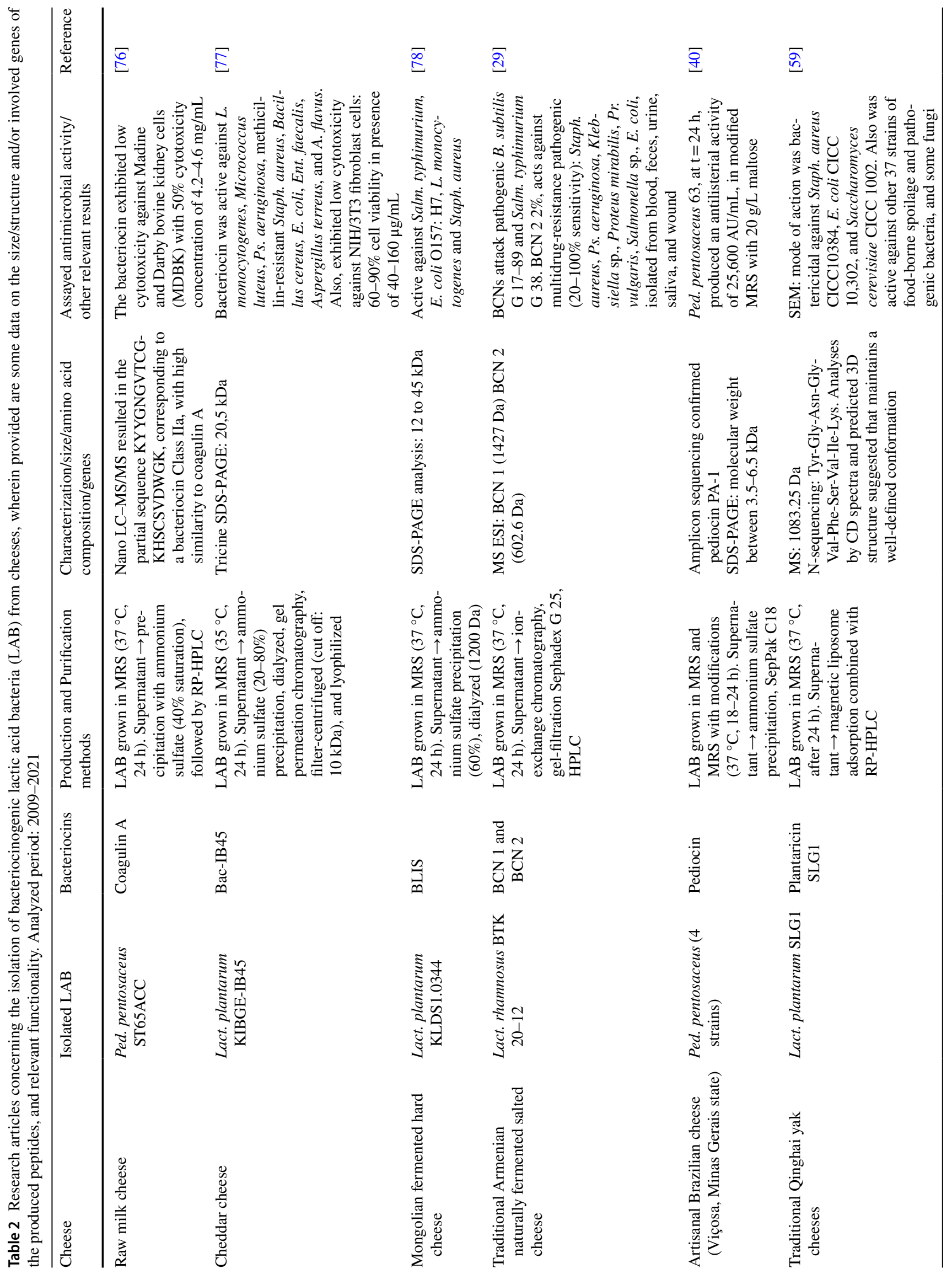




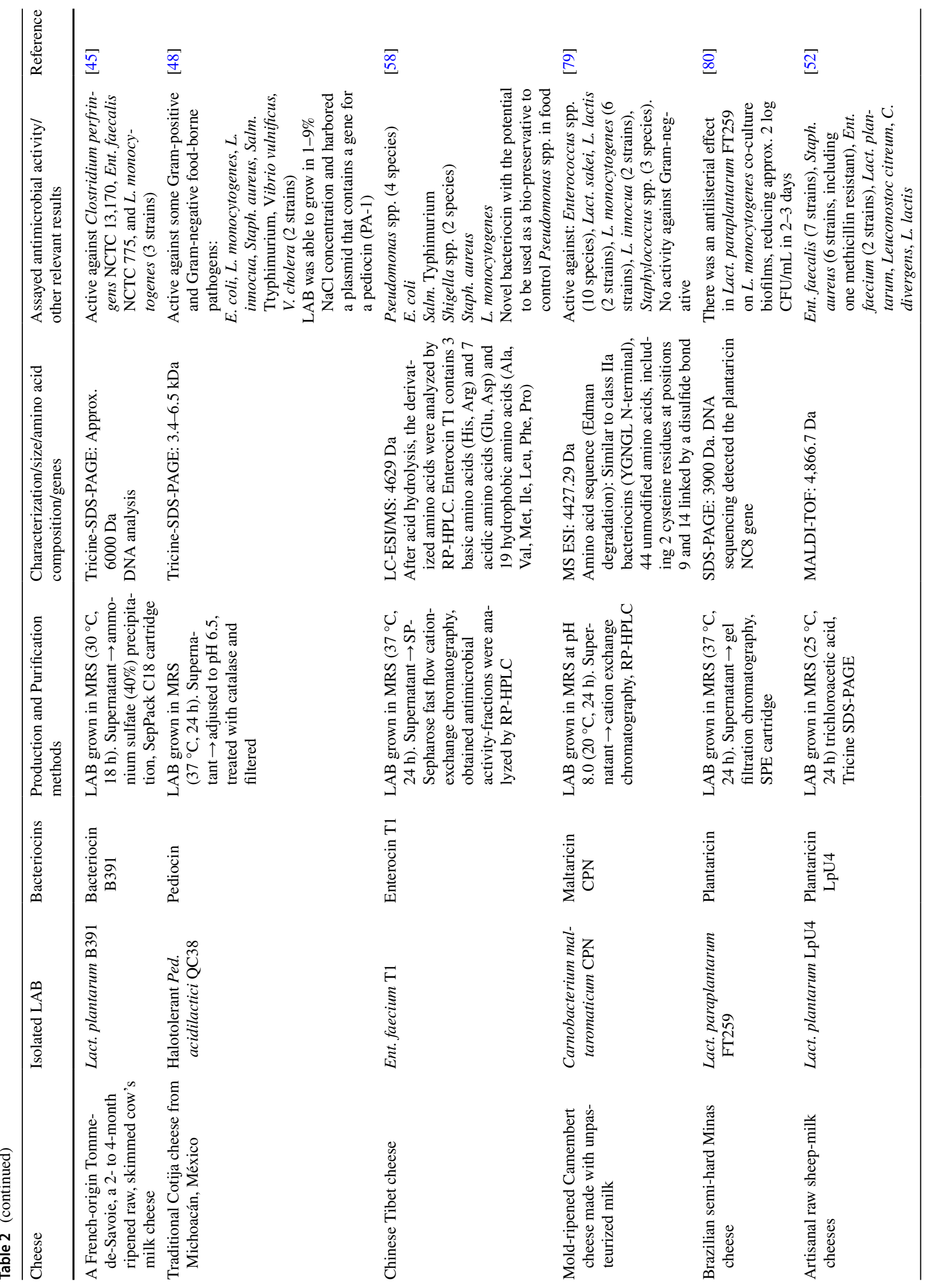




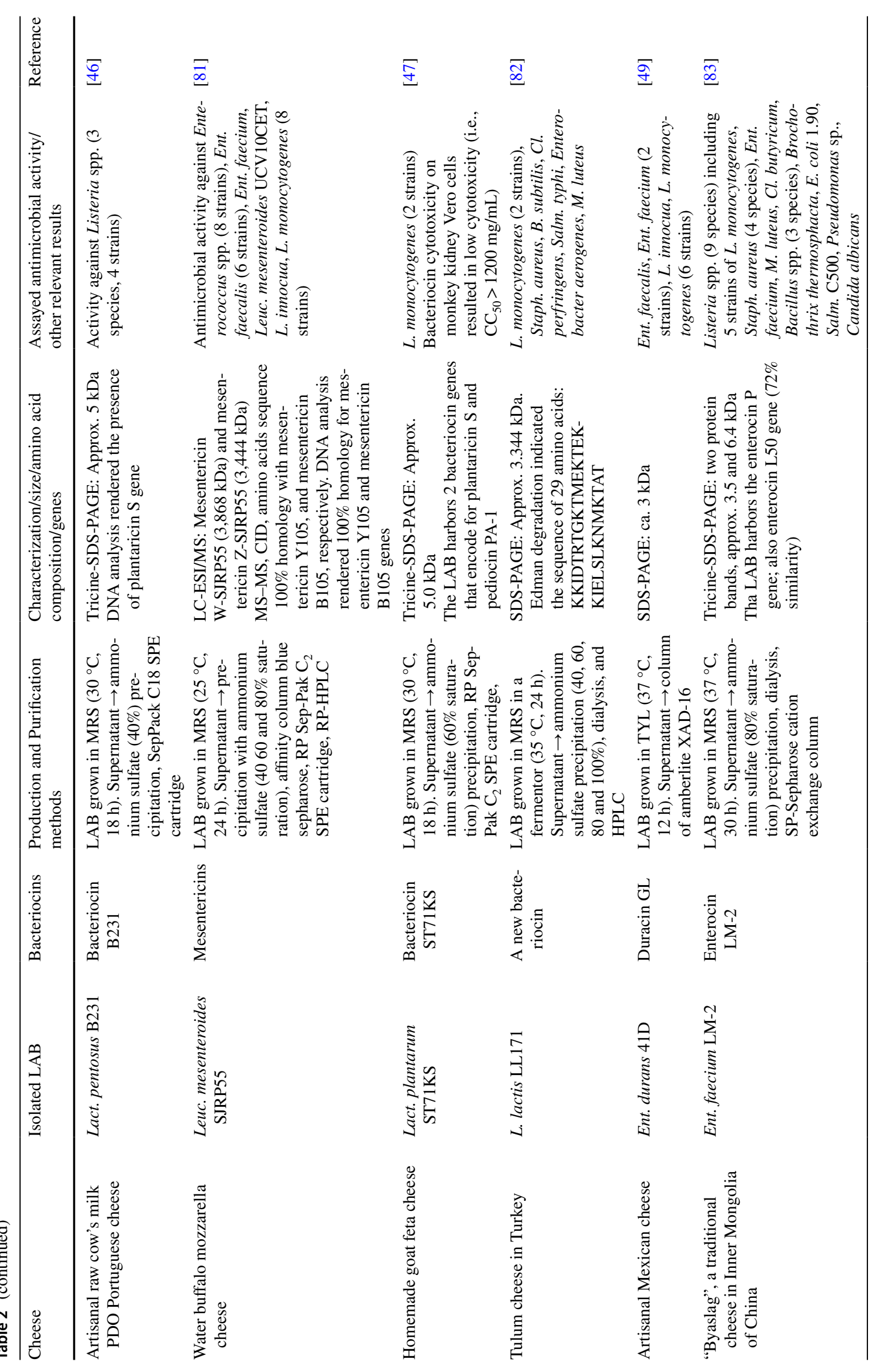




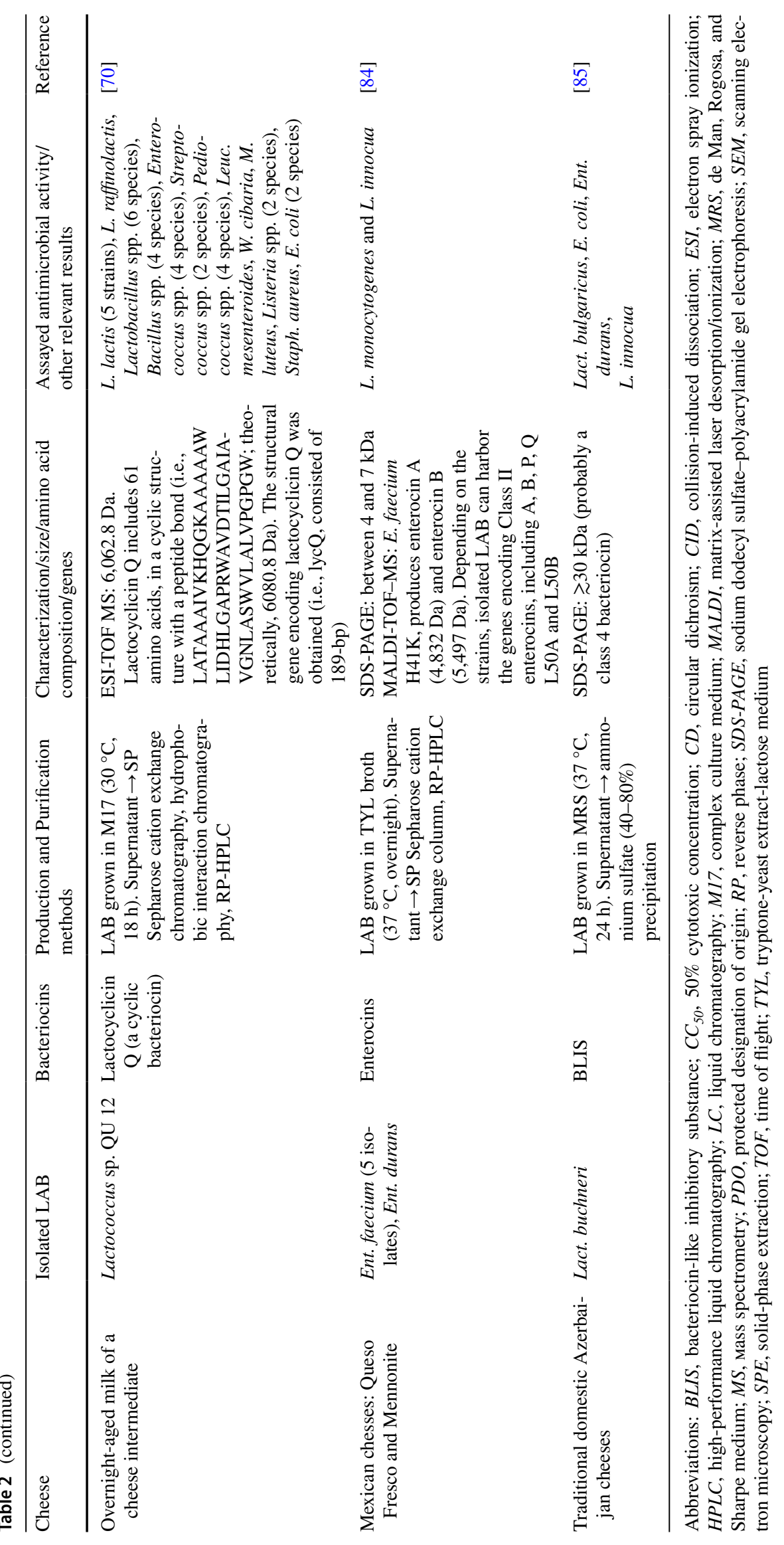


cancer, contraception, bio-nanomaterials, veterinary, oral care, skin care [69]), during the analyzed period, researchers carried out different tests to characterize such bacteriocins, including the spectrum of antimicrobial activity against food borne (i.e., L. monocytogenes, E. coli) and deterioration microorganisms, as well as some antibioticresistant pathogens (i.e., methicillin-resistant Staph. aureus (MRSA) and other nosocomial microorganisms); cytotoxicity against some eukaryotic cells (i.e., monkey kidney Vero cells; Madine and Darby bovine kidney cells); molecular size by mass spectrometry (MS) (i.e., ESI (electron spray ionization)-(time-of-flight) TOF-MS; liquid chromatography (LC)-ESI/MS), matrix-assisted laser desorption/ionization (MALDI) (i.e., MALDI-TOF), and sodium dodecyl sulfate-polyacrylamide gel electrophoresis (SDS-PAGE); bacteriocin encoding gene sequencing analysis in DNA; and partial or total amino acid sequencing of the functional peptides (Table 2). Also, the activity of the produced bacteriocins is evaluated after adverse treatment conditions of heating (i.e., $100-120^{\circ} \mathrm{C}$ for $15-30 \mathrm{~min}$ ), low temperatures (i.e., $-20{ }^{\circ} \mathrm{C}$ during several months), $\mathrm{pH}$ (i.e., interval $3-10$ ), the enzymatic activity of proteases of pancreatic and gastric origin (i.e., $\alpha$-chymotrypsin, trypsin, pepsin), fungal (i.e., proteinase $\mathrm{K}$ ) and bacterial (i.e., pronase $\mathrm{E}$ ) proteases, and/or other enzymes (i.e., $\alpha$-amylase, lipase A), among other tests.

\section{Perspectives}

The challenge is enormous; the requirement of new and better bacteriocins is a constant demand in the food industry, mainly for the bioconservation of processed foods, but also is the opportunity to be applied within the pharmaceutical industry and in human and animal medicine fields, particularly to combat the antibiotic-resistant pathogens (i.e., MRSA), cancer, and its possible role as gut microbiome modulators, among other potential applications. Here is a plus benefit of traditional cheeses as real mines for the isolation of bacteriocin-producing LAB. Nevertheless, hard work is required for new bacteriocins are commercially available (once appropriate LAB have been isolated), not only concerning the biotechnological process development matters, but particularly fulfilling the requirements of the regulatory agencies like the World Health Organization (WHO), and Food and Agriculture Organization (FAO), as well as the regional agencies involved (i.e., Food and Drug Administration (FDA) in the USA; European Food Safety Authority (EFSA) in Europe), to guarantee the safe use of such bacteriocins.

Acknowledgements LTG and AEGC are CONACyT-México fellowships for PhD. and MSc. studies at UAEH, respectively.
Data Availability The data that support the findings of this study are available from the corresponding author upon reasonable request.

\section{Declarations}

Competing Interests The authors declare no competing interests.

\section{References}

1. Franz CMAP, Holzapfel WH (2011) The importance of understanding the stress physiology of lactic acid bacteria. In: Tsakalidou E, Papadimitriou K (ed) Stress responses of lactic acid bacteria. Springer, USA, pp 3-20. https://doi.org/10.1007/978-0-387-92771-8_1

2. Todorov SD, Holzapfel W, Nero LA (2015) Characterization of a novel bacteriocin produced by Lactobacillus plantarum ST8SH and some aspects of its mode of action. Ann Microbiol 66(3):949962. https://doi.org/10.1007/s13213-015-1180-4

3. Heng NCK, Wescombe PA, Burton JP, Jack RW, Tagg JR (2007) The diversity of bacteriocins in gram-positive bacteria. In: Riley MA, Chavan MA (eds) Bacteriocins: ecology and evolution. Springer, Germany, pp 45-92

4. Bogovič-Matijašić B, Rogelj I (2011) Bacteriocins of probiotics and enteric cytoprotection. In: Malago JJ, Koninkx JFJG, MarinsekLogar R (ed) Probiotic bacteria and enteric infections. Cytoprotection by probiotic bacteria. Springer, Netherlands, pp 313-354. https://doi.org/10.1007/978-94-007-0386-5_14

5. Zimina M, Babich O, Prosekov A, Sukhikh S, Ivanova S, Shevchenko M, Noskova S (2020) Overview of global trends in classification, methods of preparation and application of bacteriocins. Antibiotics 9(9)553. https://doi.org/10.3390/antibiotics9090553

6. Negash AW, Tsehai BA (2020) Current applications of bacteriocin. Int J Microbol 2020:1-7. https://doi.org/10.1155/2020/4374891

7. Ashaolu TJ (2019) A review on selection of fermentative microorganisms for functional foods and beverages: the production and future perspectives. Int J Food Sci Tech 54(8):2511-2519. https:// doi.org/10.1111/ijfs.14181

8. Steinkraus KH (2002) Fermentations in world food processing. Compr Rev Food Sci Food Saf 1:23-32

9. Panwar H, Calderwood D, Grant IR, Grover S, Green BD (2014) Lactobacillus strains isolated from infant faeces possess potent inhibitory activity against intestinal alpha- and beta-glucosidases suggesting anti-diabetic potential. Eur J Nutr 53(7):1465-1474. https://doi.org/10.1007/s00394-013-0649-9

10. Fernandez-Juri MG, Muzzolon JA, Dalcero AM, Magnoli CE (2011) Effect of acid lactic bacteria isolated from faeces of healthy dogs on growth parameters and aflatoxin $\mathrm{B}_{1}$ production by Aspergillus species in vitro. Mycotox Res 27(4):273-280. https://doi. org/10.1007/s12550-011-0104-9

11. Niederle MV, Bosch J, Ale CE, Nader-Macias ME, Aristimuno Ficoseco C, Toledo LF, Valenzuela-Sanchez A, Soto-Azat C, Pasteris SE (2019) Skin-associated lactic acid bacteria from North American bullfrogs as potential control agents of Batrachochytrium dendrobatidis. PLoS One 14(9):e0223020. https:// doi.org/10.1371/journal.pone.0223020

12. Terai T, Okumura T, Imai S, Nakao M, Yamaji K, Ito M, Nagata T, Kaneko K, Miyazaki K, Okada A, Nomura Y, Hanada N (2015) Screening of probiotic candidates in human oral bacteria for the prevention of dental disease. PLoS One 10(6):e0128657. https:// doi.org/10.1371/journal.pone.0128657

13. Todorov SD, Botes M, Danova ST, Dicks LM (2007) Probiotic properties of Lactococcus lactis ssp. lactis HV219, isolated from human vaginal secretions. J Appl Microbiol 103(3):629-39. https://doi.org/10.1111/j.1365-2672.2007.03290.x 
14. Teneva-Angelova T, Beshkova D (2015) Non-traditional sources for isolation of lactic acid bacteria. Ann Microbiol 66(1):449-459. https://doi.org/10.1007/s13213-015-1127-9

15. Mattick ATR, Hirsch A, Berridge NJ (1947) Further observations on an inhibitory substance (nisin) from lactic streptococci. The Lancet 250(6462):5-8. https://doi.org/10.1016/S0140-6736(47)90004-4

16. FDA (2000) Nisin GRAS Notice Information. Center for Food Safety and Applied Nutrition. https://www.fda.gov/downloads/food/ ingredientspackaginglabeling/gras/noticeinventory/ucm266587.pdf

17. EFSA (2017) Safety of nisin (E 234) as a food additive in the light of new toxicological data and the proposed extension of use. EFSA J 15(12):e05063. https://doi.org/10.2903/j.efsa.2017.5063

18. FDA (2016) GRAS Notice for colicin antimicrobial product for use on meat products. Center for Food Safety and Applied Nutrition. http://www.fda.gov/Food/IngredientsPackagingLabeling/ GRAS/NoticeInventory/default.htm

19. Okuda K, Zendo T, Sugimoto S, Iwase T, Tajimam A, Yamada S, Sonomoto K, Mizunoe Y (2013) Effects of bacteriocins on methicillin-resistant Staphylococcus aureus biofilm. Antimicrob Agents Chemother 57(11):5572-5579. https://doi.org/10.1128/ AAC.00888-13

20. Zainodini N, Hassanshahi G, Hajizadeh M, Khanamani FalahatiPour S, Mahmoodi M, Mirzaei MR (2018) Nisin induces cytotoxicity and apoptosis in human asterocytoma cell line (SW1088). Asian Pac J Cancer Prev 19(8):2217-2222. https://doi.org/10. 22034/APJCP.2018.19.8.2217

21. Tsai TL, Li AC, Chen YC, Liao YS, Lin TH (2015) Antimicrobial peptide $\mathrm{m} 2163$ or m2386 identified from Lactobacillus casei ATCC 334 can trigger apoptosis in the human colorectal cancer cell line SW480. Tumour Biol 36(5):3775-3789. https://doi.org/ 10.1007/s13277-014-3018-2

22. Elnagdy S, AlKhazindar M (2020) The potential of antimicrobial peptides as an antiviral therapy against COVID-19. ACS Pharmacol Transl Sci 3(4):780-782. https://doi.org/10.1021/acsptsci.0c00059

23. Wang G, Li X, Wang Z (2016) APD3: the antimicrobial peptide database as a tool for research and education. Nucleic Acids Res 44:1087-1093. https://doi.org/10.1093/nar/gkv1278

24. Papademas P, Bintsis T (2018) Global cheesemaking technology. Cheese quality and characteristics. John Wiley \& Sons, India

25. Fox PF, Guinee TP, Cogan TM, McSweeney PLH (2017) Fundamentals of cheese science. Springer, New York

26. Yang E, Fan L, Jiang Y, Doucette C, Fillmore S (2012) Antimicrobial activity of bacteriocin-producing lactic acid bacteria isolated from cheeses and yogurts. AMB Express 2(1):48. http:// doi.org/https://doi.org/10.1186/2191-0855-2-48

27. Aria M, Cuccurullo C (2017) bibliometrix : an R-tool for comprehensive science mapping analysis. J Informetr 11(4):959-975. https://doi.org/10.1016/j.joi.2017.08.007

28. Karska-Wysocki B, Bazo M, Smoragiewicz W (2010) Antibacterial activity of Lactobacillus acidophilus and Lactobacillus casei against methicillin-resistant Staphylococcus aureus (MRSA). Microbiol Res 165(8):674-686. https://doi.org/10.1016/j.micres. 2009.11.008

29. Tkhruni FN, Aghajanyan AE, Balabekyan TR, Khachatryan TV, Karapetyan KJ (2020) Characteristic of bacteriocins of Lactobacillus rhamnosus BTK 20-12 potential probiotic strain. Probiotics Antimicrob Proteins 12(2):716-724. https://doi.org/10.1007/ s12602-019-09569-y

30. Heredia-Castro PY, Hernández-Mendoza A, González-Córdova AF, Vallejo-Cordoba B (2017) Bacteriocinas de bacterias ácido lácticas: Mecanismos de acción y actividad antimicrobiana contra patógenos en quesos. Interciencia 42(6):340-346

31. Ghaffar T, Irshad M, Anwar Z, Aqil T, Zulifqar Z, Tariq A, Kamran M, Ehsan N, Mehmood S (2014) Recent trends in lactic acid biotechnology: a brief review on production to purification. J Radiat Res Appl Sci 7(2):222-229. https://doi.org/10.1016/j.jrras.2014.03.002
32. Daw Mohamed AFFR (1996) Bacteriocins: nature, function and structure. Micron 27:467-479

33. Nuraida L (2015) A review: health promoting lactic acid bacteria in traditional Indonesian fermented foods. Food Sci Hum Well 4(2):47-55. https://doi.org/10.1016/j.fshw.2015.06.001

34. Cavicchioli VQ, Camargo AC, Todorov SD, Nero LA (2019) Potential control of Listeria monocytogenes by bacteriocinogenic Enterococcus hirae ST57ACC and Pediococcus pentosaceus ST65ACC strains isolated from artisanal cheese. Probiotics Antimicrob Proteins 11(2):696-704. https://doi.org/10.1007/ s12602-018-9449-0

35. Campagnollo FB, Margalho LP, Kamimura BA, Feliciano MD, Freire L, Lopes LS, Alvarenga VO, Cadavez VAP, Gonzales-Barron U, Schaffner DW, Sant'Ana AS (2018) Selection of indigenous lactic acid bacteria presenting anti-listerial activity, and their role in reducing the maturation period and assuring the safety of traditional Brazilian cheeses. Food Microbiol 73:288-297. https://doi.org/10. 1016/j.fm.2018.02.006

36. García-Cano I, Serrano-Maldonado CE, Olvera-García M, Delgado-Arciniega E, Peña-Montes C, Mendoza-Hernández G, Quirasco M (2014) Antibacterial activity produced by Enterococcus spp. isolated from an artisanal Mexican dairy product, Cotija cheese. LWT - Food Sci Technol 59(1):26-34. https://doi.org/10. 1016/j.lwt.2014.04.059

37. Deegan LH, Cotter PD, Hill C, Ross P (2006) Bacteriocins: biological tools for bio-preservation and shelf-life extension. Int Dairy J 16(9):1058-1071. https://doi.org/10.1016/j.idairyj.2005. 10.026

38. Sip A, Więckowicz M, Olejnik-Schmidt A, Grajek W (2012) Anti-listeria activity of lactic acid bacteria isolated from golka, a regional cheese produced in Poland. Food Control 26(1):117-124. https://doi.org/10.1016/j.foodcont.2012.01.014

39. Vera Pingitore E, Todorov SD, Sesma F, Franco BD (2012) Application of bacteriocinogenic Enterococcus mundtii CRL35 and Enterococcus faecium ST88Ch in the control of Listeria monocytogenes in fresh Minas cheese. Food Microbiol 32(1):38-47. https://doi.org/10.1016/j.fm.2012.04.005

40. Gutiérrez-Cortés C, Suarez H, Buitrago G, Nero LA, Todorov SD (2018) Characterization of bacteriocins produced by strains of Pediococcus pentosaceus isolated from Minas cheese. Ann Microbiol 68:383-398. https://doi.org/10.1007/ s13213-018-1345-z

41. Cabral Carvalhaes Costa AC, Neves Pereira A, De Andrade e Silva AC, Alves da Silva F, De Oliverira Ribeiro K, Sapateiro Torres IM, Pereira De Martinis EC, Farías Alves V (2018) Antilisterial and antistaphylococcal activity of a Lactococcus lactis strain isolated from Brazilian fresh Minas cheese. J Food Saf 39(1). https:// doi.org/10.1111/jfs. 12593

42. Nespolo CR, Brandelli A (2010) Production of bacteriocin-like substances by lactic acid bacteria isolated from regional ovine cheese. Braz J Microbiol 41:1009-1018

43. Olbrich dos Santos KM, Vieira ADS, Rocha CRC, do Nascimento JCF, de Souza Lopes AC, Bruno LM, Carvalho JDG, de Melo Franco BDG, Todorov SD (2014) Brazilian artisanal cheeses as a source of beneficial Enterococcus faecium strains: characterization of the bacteriocinogenic potential. Ann Microbiol 64(4):1463-1471. https://doi.org/10.1007/s13213-013-0789-4

44. Tulini FL, Carrer Gomes B, Pereira de Martinis EC (2011) Partial purification and characterization of a bacteriocin produced by Enterococcus faecium 130 isolated from mozzarella cheese. Ciência Tecnol Alime 31(1):155-159

45. Fernandes P, Loureiro D, Monteiro V, Ramos C, Nero LA, Todorov SD, Guerreiro JS (2017) Lactobacillus plantarum isolated from cheese: production and partial characterization of bacteriocin B391. Ann Microbiol 67(6):433-442. https://doi.org/10. 1007/s13213-017-1275-1 
46. Guerreiro J, Monteiro V, Ramos C, Franco BD, Martinez RC, Todorov SD, Fernandes P (2014) Lactobacillus pentosus B231 isolated from a portuguese PDO cheese: production and partial characterization of its bacteriocin. Probiotics Antimicrob Proteins 6(2):95-104. https://doi.org/10.1007/s12602-014-9157-3

47. Chacon Ruiz Martinez R, Wachsman M, Torres NI, LeBlanc JG, Todorov SD, Franco BD (2013) Biochemical, antimicrobial and molecular characterization of a noncytotoxic bacteriocin produced by Lactobacillus plantarum ST71KS. Food Microbiol 34(2):376381. https://doi.org/10.1016/j.fm.2013.01.011

48. Morales-Estrada AI, Ruiz EA, López-Merino A, Contreras-Rodríguez A, Gutierrez-Mendez N (2016) Partial characterization of bacteriocin produced by halotolerant Pediococcus acidilactici strain QC38 isolated from traditional Cotija cheese. Pol J Microbiol 65(3):279-285

49. Du L, Somkuti GA, Renye JA Jr, Huo G (2012) Properties of Durancin Gl, a new antilisterial bacteriocin produced by Enterococcus Durans 41d. J Food Saf 32(1):74-83. https://doi.org/10. 1111/j.1745-4565.2011.00346.x

50. Ribeiro SC, Coelho MC, Todorov SD, Franco BD, Dapkevicius ML, Silva CC (2014) Technological properties of bacteriocin-producing lactic acid bacteria isolated from Pico cheese an artisanal cow's milk cheese. J Appl Microbiol 116(3):573-585. https://doi.org/10.1111/ jam. 12388

51. Ołdak A, Zielińska D, Łepecka A, Długosz E, Kołożyn-Krajewska D (2020) Lactobacillus plantarum strains isolated from Polish regional cheeses exhibit anti-staphylococcal activity and selected probiotic properties. Probiotics Antimicrob Proteins 12:10251038. https://doi.org/10.1007/s12602-019-09587-w

52. Milioni C, Martínez B, Degl'Innocenti S, Turchi B, Fratini F, Cerri D, Fischetti R (2015) A novel bacteriocin produced by Lactobacillus plantarum LpU4 as a valuable candidate for biopreservation in artisanal raw milk cheese. Dairy Sci \& Technol 95(4):479-494. https://doi.org/10.1007/s13594-015-0230-9

53. Mirkovic N, Radulovic Z, Obradovic D, Uzelac G, Topisirovic L, Lozo J, Kojic M (2015) Isolation and characterisation of cacteriocin and aggregation-promoting factor production in Lactococcus lactis ssp. lactis BGBM50 Strain. Food Technol Biotechnol 53(2):237-242. https://doi.org/10.17113/ftb.53.02.15.3846

54. Ahmadova A, Todorov SD, Choiset Y, Rabesona H, Mirhadi Zadi T, Kuliyev A, Franco BDGdM, Chobert JM, Haertlé T (2013) Evaluation of antimicrobial activity, probiotic properties and safety of wild strain Enterococcus faecium AQ71 isolated from Azerbaijani Motal cheese. Food Control 30(2):631-641. https:// doi.org/10.1016/j.foodcont.2012.08.009

55. Nayyeri N, Edalatian Dovom MR, Habibi Najafi MB, Bahreini M (2017) A preliminary study on antifungal activity of lactic acid bacteria isolated from different production stages of Lighvan cheese on Penicillium expansum and Rhodotorula mucilaginosa. J Food Meas Charact 11(4):1734-1744. https://doi.org/10.1007/ s11694-017-9554-x

56. Jabbari V, Khiabani MS, Mokarram RR, Hassanzadeh AM, Ahmadi E, Gharenaghadeh S, Karimi N, Kafil HS (2017) Lactobacillus plantarum as a probiotic potential from Kouzeh cheese (Traditional Iranian Cheese) and its antimicrobial activity. Probiotics Antimicrob Proteins 9(2):189-193. https://doi.org/10.1007/s12602-017-9255-0

57. İspirli H, Demirbas F, Dertli E (2017) Characterization of functional properties of Enterococcus spp. isolated from Turkish white cheese. LWT - Food Sci Technol 75:358-365. https://doi.org/10. 1016/j.lwt.2016.09.010

58. Liu H, Zhang L, Yi H, Han X, Gao W, Chi C, Song W, Li H, Liu C (2016) A novel enterocin T1 with anti-Pseudomonas activity produced by Enterococcus faecium $\mathrm{T} 1$ from Chinese Tibet cheese. World J Microbiol Biotechnol 32(2):21. https://doi.org/10.1007/ s11274-015-1973-4

59. Pei J, Li X, Han H, Tao Y (2018) Purification and characterization of plantaricin SLG1, a novel bacteriocin produced by $L b$. plantarum isolated from yak cheese. Food Control 84:111-117. https://doi.org/10.1016/j.foodcont.2017.07.034

60. El-Ghaish S, Khalifa M, Elmahdy A, (2017) Antimicrobial impact for Lactococcus lactis subsp. lactis A15 and Enterococcus faecium A15 isolated from some traditional Egyptian dairy products on some pathogenic bacteria. J Food Biochem 41(1):e12279. https://doi.org/10.1111/jfbc. 12279

61. De Man JC, Rogosa M, Sharpe ME (1960) A medium for the cultivation of lactobacilli. J Apl Microbiol 23(1):130-135. https:// doi.org/10.1111/j.1365-2672.1960.tb00188.x

62. Terzaghi BE, Sandine WE (1975) Improved medium for lactic streptococci and their bacteriophages. Appl microbiol 29(6):807813. https://doi.org/10.1128/am.29.6.807-813.1975

63. Somkuti GA, Steinberg DH (1979) Adaptability of Streptococcus thermophilus to lactose, glucose and galactose. J Food Prot 42(11):881-887. https://doi.org/10.4315/0362-028x-42.11.881

64. Garsa AK, Kumariya R, Sood SK, Kumar A, Kapila S (2014) Bacteriocin production and different strategies for their recovery and purification. Probiotics Antimicrob Proteins 6(1):47-58. https:// doi.org/10.1007/s12602-013-9153-z

65. Mokoena MP (2017) Lactic acid bacteria and their bacteriocins: classification, biosynthesis and applications against uropathogens: a mini-review. Molecules 22(8). https://doi.org/10.3390/ molecules22081255

66. Garcia-Curiel L, Lopez-Cuellar MR, Rodriguez-Hernandez AI, Chavarria-Hernandez N (2021) Toward understanding the signals of bacteriocin production by Streptococcus spp. and their importance in current applications. World J Microbiol Biotechnol 37(1):15. https://doi.org/10.1007/s11274-020-02973-5

67. Campanero C, Munoz-Atienza E, Diep DB, Feito J, Arbulu S, Del Campo R, Nes IF, Hernandez PE, Herranz C, Cintas LM (2020) Biochemical, genetic and transcriptional characterization of multibacteriocin production by the anti-pneumococcal dairy strain Streptococcus infantarius LP90. PLoS One 15(3):e0229417. https://doi. org/10.1371/journal.pone.0229417

68. Zou J, Jiang H, Cheng H, Fang J, Huang G (2018) Strategies for screening, purification and characterization of bacteriocins. Int $\mathrm{J}$ Biol Macromol 117:781-789. https://doi.org/10.1016/j.ijbiomac. 2018.05.233

69. López-Cuellar MdR, Rodríguez-Hernández AI, ChavarríaHernández N (2016) LAB bacteriocin applications in the last decade. Biotechnol Biotechnol Equip 30(6):1039-1050. https:// doi.org/10.1080/13102818.2016.1232605

70. Sawa N, Zendo T, Kiyofuji J, Fujita K, Himeno K, Nakayama J, Sonomoto K (2009) Identification and characterization of lactocyclicin Q, a novel cyclic bacteriocin produced by Lactococcus sp. strain QU 12. Appl Environ Microbiol 75(6):1552-8. https:// doi.org/10.1128/AEM.02299-08

71. Favaro L, Basaglia M, Casella S, Hue I, Dousset X, de Melo G, Franco BD, Todorov SD (2014) Bacteriocinogenic potential and safety evaluation of non-starter Enterococcus faecium strains isolated from home made white brine cheese. Food Microbiol 38:228-239. https://doi.org/10.1016/j.fm.2013.09.008

72. Alegria A, Delgado S, Roces C, Lopez B, Mayo B (2010) Bacteriocins produced by wild Lactococcus lactis strains isolated from traditional, starter-free cheeses made of raw milk. Int J Food Microbiol 143(1-2):61-66. https://doi.org/10.1016/j.ijfoodmicro.2010.07.029

73. Simova ED, Beshkova DB, Dimitrov ZhP (2009) Characterization and antimicrobial spectrum of bacteriocins produced by lactic acid bacteria isolated from traditional Bulgarian dairy products. J Appl Microbiol 106(2):692-701. https://doi.org/10.1111/j.1365-2672. 2008.04052.x

74. Rushdy AA, Gomaa EZ (2013) Antimicrobial compounds produced by probiotic Lactobacillus brevis isolated from dairy products. Ann Microbiol 63(1):81-90. https://doi.org/10.1007/ s13213-012-0447-2 
75. Moraes PM, Perin LM, Tassinari Ortolani MB, Yamazi AK, Viçosa GN, Nero LA (2010) Protocols for the isolation and detection of lactic acid bacteria with bacteriocinogenic potential. LWT - Food Sci Technol 43(9):1320-1324. https://doi.org/10.1016/j.lwt.2010. 05.005

76. Todorov SD, Cavicchioli VQ, Ananieva M, Bivolarski VP, Vasileva TA, Hinkov AV, Todorov DG, Shishkov S, Haertle T, Iliev IN, Nero LA, Ivanova IV (2020) Expression of coagulin A with low cytotoxic activity by Pediococcus pentosaceus ST65ACC isolated from raw milk cheese. J Appl Microbiol 128(2):458-472. https://doi.org/10. 1111/jam. 14492

77. Ibrahim F, Siddiqui NN, Aman A, Qader SAU, Ansari A (2019) Characterization, cytotoxic analysis and action mechanism of antilisterial bacteriocin produced by Lactobacillus plantarum isolated from cheddar cheese. Int J Pept Res Ther 26(4):1751-1764. https://doi.org/10.1007/s10989-019-09982-5

78. Muhammad Z, Ramzan R, Abdelazez A, Amjad A, Afzaal M, Zhang S, Pan S (2019) Assessment of the antimicrobial potentiality and functionality of Lactobacillus plantarum strains isolated from the conventional inner Mongolian fermented cheese against foodborne pathogens. Pathogens 8(2). https://doi.org/10.3390/ pathogens 8020071

79. Hammi I, Delalande F, Belkhou R, Marchioni E, Cianferani S, Ennahar S (2016) Maltaricin CPN, a new class IIa bacteriocin produced by Carnobacterium maltaromaticum CPN isolated from mould-ripened cheese. J Appl Microbiol 121(5):1268-1274. https://doi.org/10.1111/jam.13248

80. Winkelströter LK, Tulini FL, De Martinis ECP (2015) Identification of the bacteriocin produced by cheese isolate Lactobacillus paraplantarum FT259 and its potential influence on Listeria monocytogenes biofilm formation. LWT - Food Scie Technol 64(2):586-592. https:// doi.org/10.1016/j.lwt.2015.06.014

81. de Paula AT, Jeronymo-Ceneviva AB, Silva LF, Todorov SD, Franco BD, Choiset Y, Haertle T, Chobert JM, Dousset X, Penna
AL (2014) Leuconostoc mesenteroides SJRP55: a bacteriocinogenic strain isolated from Brazilian water buffalo mozzarella cheese. Probiotics Antimicrob Proteins 6(3-4):186-197. https:// doi.org/10.1007/s12602-014-9163-5

82. Kumari A, Akkoc N, Akcelik M (2012) Purification and partial characterization of bacteriocin produced by Lactococcus lactis ssp. lactis LL171. World J Microbiol Biotechnol 28(4):1647-55. https://doi.org/10.1007/s11274-011-0971-4

83. Liu G, Griffiths MW, Wu P, Wang H, Zhang X, Li P (2011) Enterococcus faecium $\mathrm{LM}-2$, a multi-bacteriocinogenic strain naturally occurring in "Byaslag", a traditional cheese of inner Mongolia in China. Food Control 22(2):283-289. https://doi.org/10.1016/j. foodcont.2010.07.023

84. Renye JAJr, Somkuti GA, Paul M, Van Hekken DL (2009) Characterization of antilisterial bacteriocins produced by Enterococcus faecium and Enterococcus durans isolates from Hispanic-style cheeses. J Ind Microbiol Biotechnol 36(2):261-268. https://doi. org/10.1007/s10295-008-0494-7

85. Gulahmadov SG, Abdullaeva NF, Guseinova NF, Kuliev AA, Ivanova IV, Dalgalarondo M, Chobert JM, Haertlée T (2009) Isolation and characterization of bacteriocin-like inhibitory substances from lactic acid bacteria isolated from Azerbaijan cheeses. Appl Biochem Microbiol 45(3):266-271. https://doi.org/10.1134/ s0003683809030053

86. Zheng J, Wittouck S, Salvetti E, Franz C, Harris HMB, Mattarelli P, O'Toole PW, Pot B, Vandamme P, Walter J, Watanabe K, Wuyts S, Felis GE, Ganzle MG, Lebeer S (2020) A taxonomic note on the genus Lactobacillus: Description of 23 novel genera, emended description of the genus Lactobacillus Beijerinck 1901, and union of Lactobacillaceae and Leuconostocaceae. Int J Syst Evol Microbiol 70(4):2782-2858. https://doi.org/10.1099/ijsem.0.004107

Publisher's Note Springer Nature remains neutral with regard to jurisdictional claims in published maps and institutional affiliations. 